\title{
ANTIBACTERIAL AND PHYTOCHEMICAL STUDIES OF PSIDIUM GUAJAVA LEAF EXTRACT
}

\author{
R. C. Agrawal 1 \
}

${ }^{1}$ Department of Research, Priyamvada Birla Cancer Research Institute, M.P. Birla Hospital J. R. Birla Road, Satna, Madhya Pradesh, India.

Received 16 October 2021

Accepted 16 November 2021

Published 30 November 2021

\section{CorrespondingAuthor}

R. C. Agrawal,

rcagrawal.pbcri@gmail.com

DOI

10.29121/granthaalayah.v9.i11.2021 .4297

Funding: This research received no specific grant from any funding agency in the public, commercial, or not-for-profit sectors.

Copyright: (C) 2021 The Author(s). This is an open access article distributed under the terms of the Creative Commons Attribution License, which permits unrestricted use, distribution, and reproduction in any medium, provided the original author and source are credited.

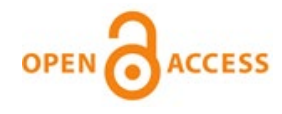

\section{ABSTRACT}

The pharmacological studies of the hydro-methanolic leaves extract of Psidium guajava was undertaken using Disk diffusion method. The secondary metabolites such as alkaloids, phenols, saponins, and tannins were present in Psidium guava extract in phytochemical screening, it also showed antibacterial activities. The study is important because different part of Psidium gujaava is used for treatment of various ailments in traditional medicine.

Keywords: Antibacterial, Photochemical, Psidium Guajava

\section{INTRODUCTION}

The roots, bark, and leaves extract of Guava or Psidium guajava are used to treat various ailments in folk medicine. Morton (1987). The fruits of Psidium guajava contain vitamin C, vitamin A, iron, calcium and phosphorus Iwu (1993). It has 5 times richer in vitamin C than oranges Conway (2001). Manganese, phosphoric, oxalic and malic acids are also present in the fruit of Guava Nadkarni and Nadkarni (1999). The guava extract was reported antimicrobial activity against different bacteria strains Iwu (1993), Gnan and Demello (1999), Pranee (1999). The leaves have antiseptic properties Hernandez (1971), antiinflammatory and analgesic activities Muruganandan et al. (2000). The ripe fruit is mildly laxative and the unripe fruit is indigestible Conway (2001). It is the remedy for diarrhea in folk medicine Wei et al. (2000).

\section{MATERIALS AND METHODS}

\subsection{EXTRACTION PROCESS}

\section{Procedure}

The Psidium gujava leaves were collected from the local area of Satna, cleaned and dried for few days in shade. Then powder was made with the help of grinder.50 gms of leaves powder was taken in a separating funnel and added $50 \%$ methanol, then mixed it gently. After every 24 hours extract was collected in a beaker till the solvent appeared colorless. The final extract was pooled together and powder was made at $40 \mathrm{o} \mathrm{C}$ in water bath. The total weight of dried powder was weighed. The desired amount of powder was dissolved in double distilled water before the final administration. Phytochemical screening was undertaken as per method reported by Agrawal, RC, 2021 


\subsection{ANTIBACTERIAL ACTIVITY}

\section{Microorganisms used}

The test organisms were obtained from the Department of Research, PBCRI Satna (M.P.). Antibacterial screening was undertaken at different concentration of $50 \%$ methanolic extract of Psidium gujava leaves the paper disc having the same diameter absorbed the concentration of extract as per method described by KirbyBauer (Disc diffusion method). The detail method is described in our published paper Agrawal (2021)

\section{RESULTS}

1) Phytochemical screening

Table 1 Phytochemical present in the hydromethanolic extract of Psidium guajava extract

\begin{tabular}{ccc}
\hline S.No. & Test & Results \\
\hline 1. & Test for Carbohydrates and reducing sugars & - \\
\hline 2 & Test for Phenolic compound's & + \\
3 & Test for Tannins & + \\
\hline 4 & Test for Proteins & + \\
\hline 5 & Test for Saponins & + \\
+ indicate present, - indicate absent. & Test for Alkaloids & \\
\end{tabular}

\section{2) Antibacterial Activitys}

Psidium guajava exhibited antibacterial activity against S.aureus, Klebsellia ,Ps auregosa and E. coli at the extract of leaves of at the different concentration

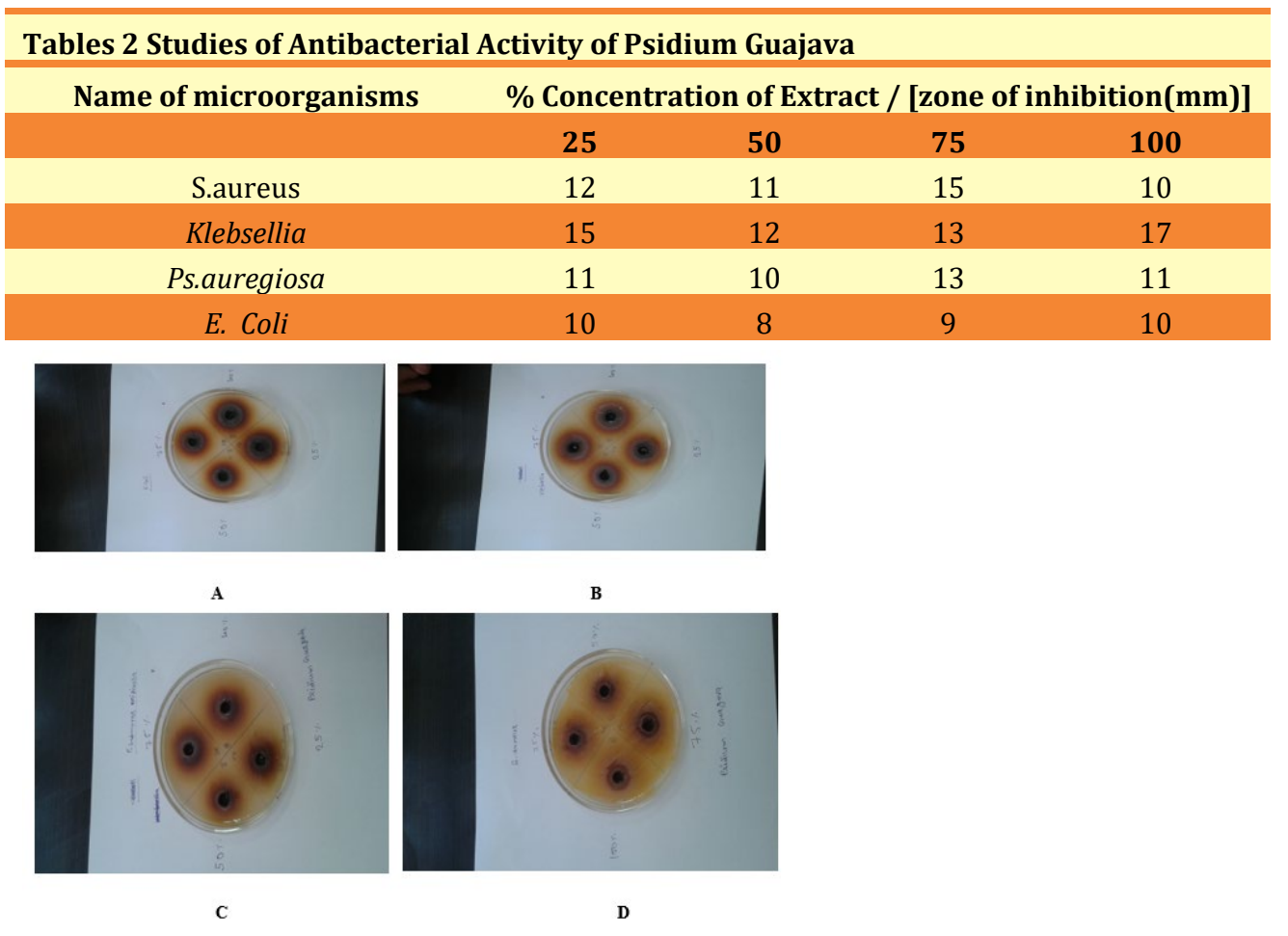

Figure 1 showed A, B, C and D showed the zone of inhibitions 


\section{DISCUSSION AND CONCLUSION}

Recent scientific research has established the presence of many active compounds in this plant that are known to possess specific pharmacological properties. Present study showed that Psidium guajava leaves extract caused antimicrobial activity against gram positive and gram-negative bacteria. These results support the findings of Egharevba et al. (2010) and Biwas et al. (2013) which also reported the antibacterial effect of guava leaves extracts and found that they inhibited the growth of S. aureus. However, the ethanolic extract showed stronger inhibition than the aqueous extract against the organisms. Phenols, saponins, Tannins and Alkaloids were present in the $50 \%$ methanolic extract of Psidium extract. Psidium Gujava may be used for development of modern drugs for various ailments.

\section{ACKNOWLEDGEMENTS}

The author is thankful to Ms. Shikhaq dahiya, Dissertation student for carring out some part of the work.

\section{REFERENCES}

Agrawal,R.C. (2021) Pharmacological studies of Mangifera indica leaves extract. World journal biology,Pharmacy and health sciences. 7 (3),73-79. Retrieved from https://doi.org/10.30574/wjbphs.2021.7.3.0100

Biwas, B., Rogers, K., McLaughlin, F., Daniels, D. and Yadav, A. (2013). Antimicrobial Activities of Leaf Extracts of Guava (Psidium guajava L.) on Two GramNegative and Gram-Positive Bacteria. International Journal of Microbiology, 1-7. Retrieved from https://doi.org/10.1155/2013/746165

Conway, Peter: (2001) Tree Medicine - a comprehensive guide to the healing power of over 170 trees. Judy Piatkus (Publishers) Ltd. Retrieved from https://doi.org/10.1016/S0962-4562(02)00076-0

Egharevba, H. O., Iliya, I., Ibekwe, N., Abdullahi, M. S., Okwute, S. K. and Okogun, J. I. (2010). Broad Spectrum Antimicrobial Activity of Psidium guajava Linn. Leaf. Nature and Science 8(12), 43-50

Gnan, S. O., Demello, M. T. (1999) Inhibition of Staphylococcus aureus by aqueous Goiaba extracts.Journal of Ethnopharmacology.68,1/3,103-108. Retrieved from https://doi.org/10.1016/S0378-8741(99)00048-3

Hernandez, Dolores F: (1971) Plants of the Philippines. M\&L Licudine Enterprises. First Printing. 2nd. edition 1980. Printed in the Philippines. University of the Philippines: Chairman: Consuelo V. Asis. D.

Iwu, Maurice M. : (1993) Handbook of African Medicinal Plants. CRC Press. ISBNNo.0-8493-4266-X.

Morton, J. (1987). Guava. In: J.F. Morton. Fruits of warm climates. Julia F. Morton, Miami, FL. p. 356-363.

Muruganandan, S.; Srinivasan, K.; Tandan, S. K.; Jawahar Lal; Suresh Chandra; Raviprakash, V.: (2000) Anti-inflammatory and analgesic activities of some medicinal plants. Journal of Medicinal and Aromatic Plant Sciences. 2001, $22 / 23,4 \mathrm{~A} / 1 \mathrm{~A}$, p.56-58. Proceedings of the National Seminar on the Frontiers of Research and Development in Medicinal Plants, Lucknow, India, 16-18 September. 
Nadkarni, K.M., Nadkarni, A.K.: (1999) Indian Materia Medica - with Ayurvedic, Unani-Tibbi, Siddha, Allopathic, Homeopathic, Naturopathic and Home remedies. Vol.1. Popular Prakashan Private Ltd., Bombay, India. ISBN No. 817154-142-9.

Pranee Jaiarj, Paranee Khoohaswan, Yuwadee Wongkrajang, Penchom Peungvicha, Potjanee Suriyawong, Saraya, M. L. S., Orawan Ruangsomboon.: (1999) Anticough and antimicrobial activities of Psidium guajava Linn. leaf extract. Journal of Ethnopharmacology,67,2,203-212. Retrieved from https://doi.org/10.1016/S0378-8741(99)00022-7

Wei L, Li Z, Chen B.: (2000) Clinical study on treatment of infantile rotaviral enteritis with Psidium guajava L. Zhongguo Zhong Xi Yi Jie $\mathrm{He} \mathrm{Za} Z$ Zhi. Dec;20(12):893-5 